\title{
Quality of care of hospitalised patients with heart failure in Poland in 2013: results of the second nationwide survey
}

\author{
Małgorzata Fedyk-Łukasik ${ }^{1}$, Barbara Wizner ${ }^{1}$, Grzegorz Opolski ${ }^{2}$, Tomasz Zdrojewski ${ }^{3}$, Marcin Czech $^{4}$, \\ Jacek S. Dubiel ${ }^{5}$, Michał Marchel ${ }^{2}$, Tomasz Rywik ${ }^{6}$, Jerzy Korewicki ${ }^{6}$, Tomasz Grodzicki ${ }^{1}$ \\ 'Department of Internal Medicine and Gerontology, Jagiellonian University Medical College, Krakow, Poland \\ ${ }^{2} 1^{\text {st }}$ Chair and Department of Cardiology, Medical University of Warsaw, Warsaw, Poland \\ ${ }^{3}$ Department of Preventive Medicine and Education, Medical University of Gdansk, Gdansk, Poland \\ ${ }^{4}$ Business School, Warsaw University of Technology, Warsaw, Poland \\ ${ }^{5} 2^{\text {nd }}$ Department of Cardiology, Jagiellonian University Medical College and University Hospital, Krakow, Poland \\ ${ }^{6}$ Department of Heart Failure and Transplantology, Institute of Cardiology, Warsaw, Poland
}

\begin{abstract}
Background: Optimal management of heart failure (HF) patients is crucial to reduce both mortality and the number of hospital admissions, at the same time improving patients' quality of life.

Aim: The aim of the study was to assess the quality of care of hospitalised patients with HF in Poland in 2013 and compare it with the results of a similar survey performed in 2005.

Methods: The presented study was conducted from April to November 2013 in a sample of 260 hospital wards in Poland, recruited by stratified proportional sampling. Similarly to the first study edition in 2005, a trained nurse contacted physicians, who filled out the study questionnaires on the last five patients with HF, who had been discharged from an internal or cardiological ward. HF did not have to be a major cause of hospital admission.

Results: The mean age of the 1300 hospitalised patients was 72.1 years, an increase of 2.3 years since the 2005 survey. The proportion of patients classified as New York Heart Association IV decreased from 28.5\% in 2005 to $22.1 \%$ in 2013. In comparison with 2005, more patients had concomitant disorders such as hypertension $(79.5 \%$ vs. $71.0 \%)$, diabetes $(46.2 \%$ vs. $33.2 \%)$, and chronic renal failure (33.4\% vs. $19.4 \%)$. Access to echocardiography has improved in recent years: it was available for $98.9 \%$ of the surveyed hospital wards (93\% in 2005$)$ and it was performed during the hospitalisation in $60.2 \%$ of the patients (58.8\% in 2005). In $2013 \mathrm{~N}$-terminal pro-B-type natriuretic peptide was accessible for $80.8 \%$ of hospital wards $(12.8 \%$ in 2005$)$ and the test was performed in $31.3 \%$ of the hospitalised patients (3.3\% in 2005). Angiotensin-converting enzyme inhibitor (ACEI) or angiotensin receptor blockers (ARB) were administered in $68.9 \%$ of HF discharged patients, beta-blockers in $84.8 \%$, mineralocorticoid receptor antagonist (MRA) in $57.9 \%$, diuretics in $85.9 \%$, and digoxin in $23 \%$. The respective numbers in 2005 were $85.9 \%, 76.0 \%, 65.4 \%, 88.9 \%$, and 38.4\%. The decrease in prescription of ACEI or ARB resulted from lesser usage of these drugs in internal medicine wards (from $84.3 \%$ in 2005 to $55.6 \%$ in 2013 ).

Conclusions: In comparison to the analogous project run in 2005, an improvement in some areas of HF treatment was observed in Polish hospitals, such as accessibility to echocardiography and natriuretic peptide measurement as well as beta-blocker and MRA use. At the same time, a meaningful decrease in ACEls or ARBs usage in internal wards was observed, which might be the result of the ageing of the HF population and an increased number of comorbidities.
\end{abstract}

Key words: heart failure, heart failure management, hospital settings, quality of care

Kardiol Pol 2017; 75, 6: 527-534 


\section{INTRODUCTION}

The prevalence of heart failure (HF) concerns approximately $1-2 \%$ of the adult population in developed countries [1], and rises among very old people $>85$ years of age [2]. According to the Working Group on Heart Failure of the Polish Cardiac Society, HF concerns 600,000 to 700,000 Polish citizens [3]. Regardless of the reduction of HF mortality that has also been observed in Poland [4], the frequency of 30-day readmissions is high and it applies to as many as every fourth patient with HF [2].

Based on National Health Fund (NHF) data, there were more than 134,000 hospitalisations related to HF in 2013, and among elderly subjects the number of octogenarians increased from $41.2 \%$ in 2009 to $47.4 \%$ in 2013 [5]. Currently, the annual costs of HF treatment are estimated at $3.7 \%$ of the NHF budget, and they are expected to double within the next 20 years. Polish data have shown that medication costs constitute less than $5 \%$ of the money spent on the treatment of $\mathrm{HF}$, while $79 \%$ is related to the hospitalisation [6]. Therefore, effective therapy of HF and limiting the number of hospitalisations among patients with HF seems mandatory.

In 2005, within the National Programme for Prevention of Cardiovascular Diseases (POLKARD 2003-2005), a nationwide survey on HF was conducted to assess the availability of diagnostic procedures and quality of medical care in randomly selected hospitals $[7,8]$. In this study we also demonstrated inequalities in access to echocardiography between academic and municipal or district hospital wards [9]. Testing B-type natriuretic peptide (BNP) levels at that time was poorly accessible, relatively expensive, and, therefore, of minor importance in everyday clinical practice [9]. However, a good adherence to guidelines on HF pharmacotherapy was observed [7].

After almost a decade, we decided to repeat the survey to assess the current situation in HF management and quality of in-hospital care of subjects, with emphasis on key diagnostic procedures and pharmacological treatment in the context of guidelines of the European Society of Cardiology (ESC). The secondary goal was to compare the results with the study performed in 2005.

\section{METHODS}

The study was a nationwide questionnaire retrospective survey. To maintain the reproducibility, the study design and methods essentially referred to the project from 2005 [7]. The second edition of this project was conducted between April and November 2013 with the participation of an external contractor, the IBC Group Central Europe Holding SA company (Warsaw, Poland).

\section{Selection of hospital/ward sample}

The method of stratified sampling was used for selection of hospitals. The first stratum was one of the 16 voivodships, the second included hospitals (regional, provincial, urban) and clinical units, having internal wards, internal wards with cardiac beds, or cardiology units. The database for the sampling of inpatient institutions was prepared based on the registry of entities carrying out medical activities (Rejestr Podmiotów Wykonujących Działalność Leczniczą) available at https:// rpwdl.csioz.gov.pl — data on April 2013. Finally, 260 hospitals were included in the study. After receiving approval from the heads of the institutions, the doctors who were invited to join the project reported data using questionnaires.

\section{Data collection and analysis}

Similarly to the first study in 2005, one physician from each surveyed hospital ward was asked to complete the study questionnaires based on the medical records of the last five patients with $\mathrm{HF}$, who were recently discharged from the hospital. HF had to be noted under the heading 'diagnosis' in the patient information card, although it did not have to be the main cause of hospitalisation. The collected information related to the HF patient's management during the last hospitalisation as well as their past medical history (e.g. invasive treatment). Moreover, some data related to diagnostic capabilities of the surveyed ward/hospital was gathered based on the physicians' declarations (e.g. access to echocardiography or N-terminal pro-B-type natriuretic peptide [NT-proBNP]). The New York Heart Association (NYHA) class of patients was determined in relation to the patient's condition on admission to the surveyed hospital ward.

Continuous variables were summarised and presented as mean \pm standard deviation (SD). Ordinal variables or variables not normally distributed were presented as median and interquartile range (IQR). Data on frequency were given as percentages. Data were managed and analysed using SAS v. 9.3 (SAS Institute Inc., Cary, NC, USA) licensed to the Jagiellonian University, Krakow, Poland.

\section{Ethical Issues}

The study obtained the approval of the Bioethics Committee of the Jagiellonian University (no. KBET/71/B/2011) — opinion of review from $28^{\text {th }}$ June 2012, expires $31^{\text {st }}$ December 2013. When gathering data, the policy of anonymity and the protection of the patient's rights were followed in compliance with the Polish law.

\section{RESULTS}

In total, 260 hospitals took part in the study and 1300 questionnaires were collected. The locations in which the institutions were active were divided into four categories in terms of size: fewer than 10,000 citizens (125 questionnaires/9.6\%), 10,000-100,000 citizens (680 questionnaires/52.3\%), 100,000-300,000 citizens (245 questionnaires/18.8\%), and more than 300,000 citizens (250 questionnaires/19.2\%).

Considering the type of inpatient institutions in the studied sample, district and urban hospitals were the most commonly represented $(38.4 \%$ and $33.7 \%$ of the institutions taking part in the selection, respectively). Of patients admitted to internal wards, $40.5 \%$ of them were treated in provincial 
hospitals (14.3\% of institutions). In teaching hospitals (13.6\% of the institutions) patients were treated mainly in cardiology departments (54.3\%).

\section{General and clinical characteristics of the studied patients}

General information about the patients involved to the survey is given in Table 1.

The main cause of hospitalisation of the patients was the exacerbation of $\mathrm{HF}(74.3 \%)$. In $14.4 \%$ of hospitalised patients HF was diagnosed de novo, in $69.7 \%$ HF was diagnosed previously (half of them three or more years prior to hospitalisation), and in $15.9 \%$ there was a lack of information. The numbers of women and men were almost equal (645 and 649, respectively). Most of the HF patients were over 60 years old $(86.5 \%)$, with a significant proportion of patients older than 80 years $(26.2 \%)$. Almost three quarters ( $74.9 \%)$ of the studied population had HF classified at admission as NYHA III-IV class.

More than $2 / 3$ of patients were diagnosed with ischaemic heart disease $(69.5 \%)$ and $4 / 5$ of patients had arterial hypertension (79.5\%). Otherwise, the most frequently diagnosed cardiovascular diseases were: atrial fibrillation, valvular heart disorders, transient ischaemic attack, or stroke. Almost half of the surveyed population were treated for diabetes, $1 / 3$ due to kidney failure, and more than $1 / 5$ of the population suffered from anaemia. The detailed clinical characteristics of the HF patients are described in Table 2.

The analysis of the case history demonstrated that before analysed hospitalisation almost half of the studied group $(n=585,43.5 \%)$ had never been treated invasively. The number of patients with electrocardiological devices inserted in the past was 242 (18.8\% of the studied population): 88 (6.8\%) had a pacemaker (PM), 19 (1.5\%) had a PM with biventricular resynchronisation option (cardiac resynchronisation therapy [CRT]), and 135 (10.5\%) had an cardioverter/defibrillator implanted (implantable cardioverter defibrillator [ICD]).

\section{Diagnostic procedures}

According to the ESC guidelines the key diagnostic procedure in HF assessment is echocardiography. In our study, the procedure was accessible for $98.9 \%$ of surveyed hospital wards, and, according to the physicians' estimations, in most cases $(90.8 \%)$ the echocardiography is usually performed within the first three days after the patient's admission. However, during the surveyed hospitalisations, echocardiography was performed only in $60.2 \%$ of the patients: among $35.3 \%$ of the patients hospitalised in internal wards, $60.7 \%$ in internal wards with cardiological beds, and among $76.7 \%$ in cardiological wards. Of those who did not have the echocardiography during the surveyed hospitalisation, $41.7 \%$ underwent the exam during the previous few months, in $23.4 \%$ more than a year ago, and in $34.4 \%$ of patients it was not defined.

The mean \pm standard deviation (SD) ejection fraction (EF) from the last available echocardiography results $(n=1255$,
Table 1. Characteristics of the population of patients with heart failure

\begin{tabular}{|lc|}
\hline Women & $645(49.6 \%)$ \\
Age [years] (mean \pm SD) & $72.1 \pm 10.1$ \\
$\quad$ median [min-max] & $73[29-104]$ \\
Age groups: & \\
$\quad \leq 59$ years & $150(11.7 \%)$ \\
$60-79$ years & $803(62.2 \%)$ \\
$\geq 80$ years & $338(26.2 \%)$ \\
NYHA class: & \\
I & $12(0.9 \%)$ \\
II & $309(23.8 \%)$ \\
III & $685(52.8 \%)$ \\
IV & $286(22.1 \%)$ \\
Number of days hospitalised, median [IQR] & $8[5-10]$ \\
\hline
\end{tabular}

Data are presented as number (percentage) and means \pm standard deviation (SD) or median and interquartile range [IQR]; NYHA — New York Heart Association

Table 2. The clinical characteristics of patients with heart failure included in the study

\begin{tabular}{|lc|} 
Prevalence of comorbidities & N (\%) \\
\hline Ischaemic heart disease & $901(69.5 \%)$ \\
Hypertension & $1034(79.5 \%)$ \\
Valvular heart disease: & \\
$\quad$ Mitral insufficiency (III/IV) & $193(15.1 \%)$ \\
$\quad$ Aortic insufficiency & $146(11.3 \%)$ \\
$\quad$ Aortic stenosis & $107(8.3 \%)$ \\
Atrial fibrillation: & \\
$\quad$ Persisted & $482(37.2 \%)$ \\
$\quad$ Paroxysmal & $253(19.6 \%)$ \\
Diabetes (pharmacologically treated) & $498(38.6 \%)$ \\
COPD or asthma & $228(17.5 \%)$ \\
Thyroid diseases & $217(16.7 \%)$ \\
TIA or stroke & $168(12.9 \%)$ \\
Chronic renal failure & $434(33.4 \%)$ \\
Anaemia & $294(22.6 \%)$ \\
Obesity or overweight & $555(42.7 \%)$ \\
Neoplasmatic diseases & $53(4.1 \%)$ \\
\hline
\end{tabular}

COPD - chronic obstructive pulmonary disease; TIA — transient ischaemic attack

$81.3 \%$ ) was $40.7 \% \pm 13.4 \%$. Among the patients with echocardiography performed during the surveyed hospitalisation, the mean EF was: $41.2 \pm 12.8$ (range: 15-72). EF data divided according to 2016 ESC guidelines for the diagnosis and treatment of acute and chronic HF showed that preserved EF (HFpEF) was present in $32.7 \%$ of patients, mid-range EF 
Table 3. Left ventricular ejection fraction (LVEF) and N-terminal pro-B-type natriuretic peptide (NT-proBNP) according to New York Heart Association (NYHA) class on admission

\begin{tabular}{lcc} 
& $\begin{array}{c}\text { LVEF }(\mathbf{n}) \\
\text { median [IQR] }\end{array}$ & $\begin{array}{c}\text { NT-proBNP }(\mathbf{n}) \\
\text { median [IQR] }\end{array}$ \\
\hline NYHA II & $\mathrm{n}=234 ; 50[34-50]$ & $\mathrm{n}=62 ; 907[656-2691]$ \\
NYHA III & $\mathrm{n}=514 ; 44[30-50]$ & $\mathrm{n}=230 ; 1100[443-3953]$ \\
NYHA IV & $\mathrm{n}=253 ; 38[29-45]$ & $\mathrm{n}=102 ; 3312[1500-6781]$ \\
\hline
\end{tabular}

Data are presented as number (percentage or score) and median and interquartile range [IQR]

(HFmrEF) was present in $23.7 \%$, and reduced EF (HFrEF) was observed in $43.6 \%$ of the patients.

NT-proBNP was accessible for $80.8 \%$ of the surveyed hospital wards, but the results of performed tests were available in $31.3 \%$ of the patients during the surveyed hospitalisation. The reason for non-performance of the test was given in $54 \%$ of cases as a lack of indications, and in $46 \%$ as too high cost.

Based on the available results, median [IQR] NT-proBNP level was 1584 [656-4197] ng/L left ventricular EF and NT-proBNP according to NYHA class on admission are presented in Table 3.

\section{Pharmacotherapy}

The analysis of pharmacotherapy demonstrated that angiotensin-converting enzyme inhibitor (ACEI) or angiotensin receptor blockers (ARB) were administered among 68.9\% of HF subjects, beta-blockers in $84.8 \%$, mineralocorticoid receptor antagonist (MRA) in $57.9 \%$, diuretics in $85.9 \%$, and digoxin in $23.0 \%$. In cases of usage of ACEI or ARB, it significantly differed according to the profile of the hospital ward - either of these drugs were prescribed in $55.6 \%$ of patients from internal wards, $70.7 \%$ of patients from internal wards with cardiological beds, and $79.4 \%$ of patients hospitalised in cardiological wards. The prescription of beta-blockers and diuretics was comparable across all wards. The usage of $\mathrm{ACEI} / \mathrm{ARB}$ in combination with beta-blockers depended on the profile of hospital ward as well: the combination was prescribed most in cardiology wards (69.1\%), less in internal wards (53.6\%). Considering the stage of HF, based on NYHA classification, it was revealed that the frequency of using beta-blockers, diuretics, MRA, and digitalis increased with HF progression (Fig. 1), while the frequency of using ACEI or ARB decreased with HF progression.

The distribution of pharmacotherapy used according to the EF value is presented in Figure 2. There were no significant differences in pharmacological treatment between genders, except for digitalis and MRA, which were more prescribed for men (respectively: $26 \%$ vs. $20 \%$ and $62 \%$ vs. $53 \%$ ). None of the patients in our study population was treated with ivabradine.
Oral anticoagulants were prescribed for $34.7 \%$ of patients, and antiplatelet treatment was administered in $49.3 \%$ of the analysed population.

\section{DISCUSSION}

The presented study measured the quality of diagnostics and therapeutic treatment in patients hospitalised due to HF, and it was done in comparison with the results of the POLKARD 2003-2005 study. According to the research of McGlynn et al. [10], only half of those suffering from chronic diseases (54.9\%) undergo the recommended medical procedures. Until now, there has been a dominant opinion that the improvement in the consistency of practice with guidelines would result in the improvement of the main indicators of treatment quality, i.e. prolongation of life, improvement of the quality of life, and decrease of hospitalisation frequency. The collected data prove that there is increasing consistency between the procedures carried out in practice and guidelines. However, the improvement in the effects of treatment measured by the number of re-hospitalisations or mortality seems to be unsatisfactory. This observation can be explained by several different hypotheses, for example by the shift in HF epidemiology. The comparison of the average age of HF patients hospitalised in Poland in 2005 and 2013 indicates that patients with HF became significantly older (69.8 years vs. 72.1 years old), and the number of octogenarians significantly increased ( $21 \%$ vs. $26 \%$ ). This observation may follow the continuous aging of the Polish population.

The population of patients with HF is characterised by common multiple-morbidity, which has a significant impact for the induction of HF decompensation. In comparison with the survey from 2005, in 2013 the percentage of people suffering from the following conditions has increased: hypertension (by 8 percentage points [pp]), valvular heart disease (by 4.7 pp), diabetes (by 13 pp), obesity (by 8.8 pp), and chronic renal failure (by 14 pp). In the case of the conditions listed above as well as in other analysed illnesses, the data is comparable with that observed in other similar studies [11]. The importance of concomitant diseases as a factor that causes HF decompensation was emphasised in the OPTIMIZE HF study by Fonarow et al. [12], who stated that there are independent factors when assessing the prognosis of HF development. Similarly, the HF Pilot Survey study conducted by the ESC in 136 clinics in 12 European countries, including Poland, showed that patients with HF and multi-morbidity were older and in a higher NYHA class [13]. It is interesting that the mean age of our study participants was higher by 6.1 years compared to the Polish cohort of the HF Pilot Survey. It was accompanied by more frequent comorbidities and more advanced HF (NYHA III $52.8 \%$ vs. $44.3 \%$, NYHA IV $22.1 \%$ vs. $17.7 \%$ ) [14]. The results of our study indicate that among hospitalised chronic HF patients the frequency of the patients who underwent the invasive procedures had increased (from $21.0 \%$ in 2005 to 


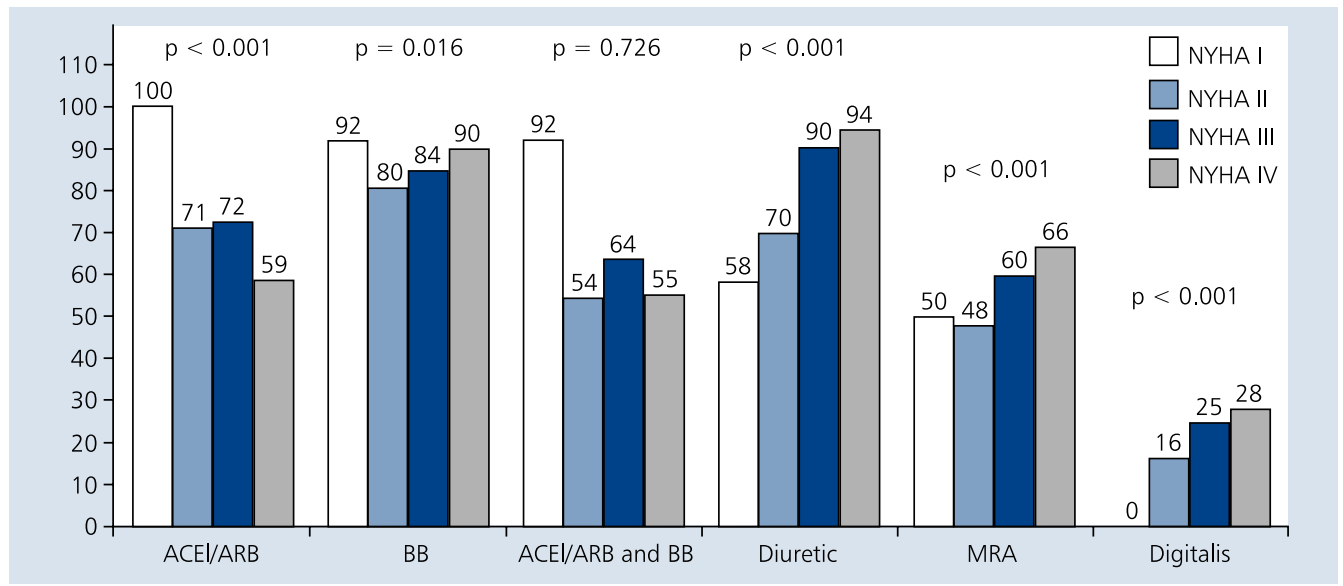

Figure 1. Medication used in heart failure treatment depending on the New York Heart Association (NYHA) classification; ACEI angiotensin-converting enzyme inhibitor; ARB — angiotensin receptor blockers; BB — beta-blocker; MRA — mineralocorticoid receptor antagonist

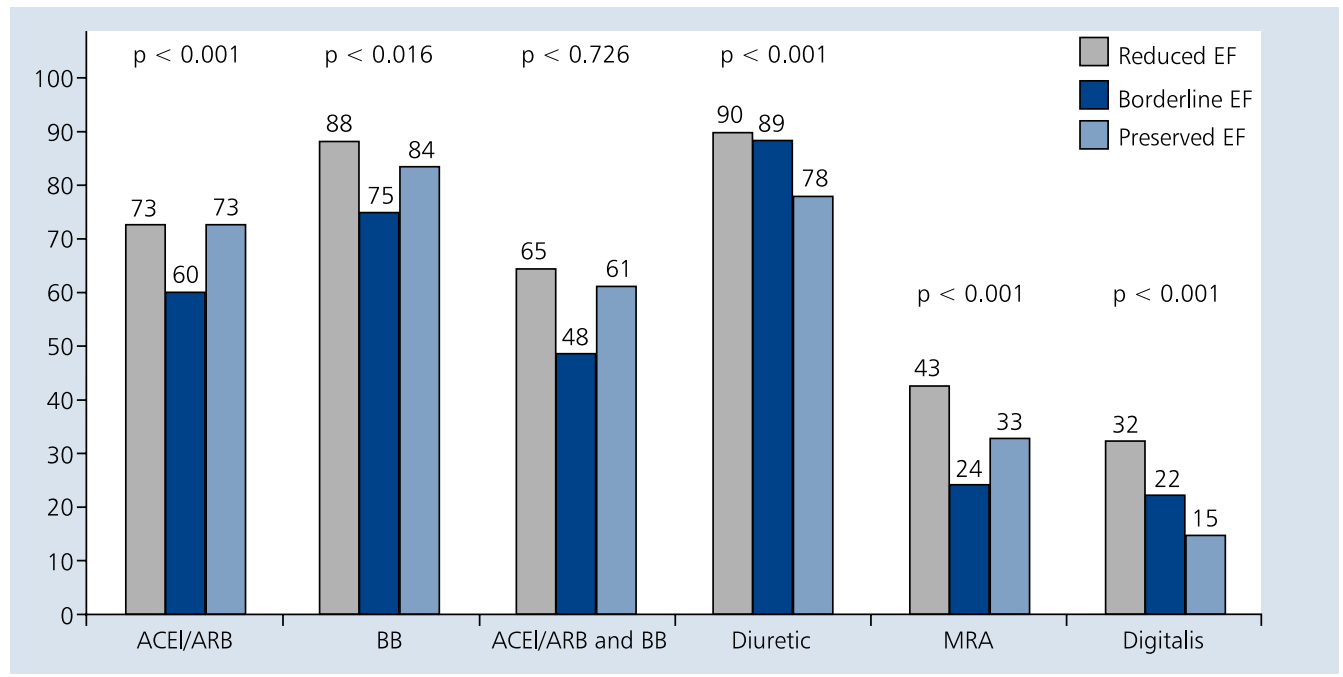

Figure 2. Medication used in heart failure treatment depending on the left ventricular ejection fraction (LVEF); ACEI — angiotensin-converting enzyme inhibitor; ARB - angiotensin receptor blockers; BB - beta-blocker; MRA - mineralocorticoid receptor antagonist

$45.3 \%$ in 2013). Of that group of patients, 163 (28.0\%) had coronary artery bypass grafting (CABG) surgery. These observations reflect the significant improvement in the accessibility of cardiac surgery procedures and the greater frequency of the indications for such procedures, which may result from the characteristics of the population with advanced HF as CABG is a method preferred for patients with a decreased EF and triple coronary arterial disease $[15,16]$.

The analysis of echocardiographic examination accessibility as a standard in HF diagnosis and therapy brings a significant improvement in comparison with 2005. The achieved outcome is probably a result of the popularisation of programmes concentrated on improving the accessibility of necessary equipment (structural indicator of treatment qual- ity), i.e. medium- and high-class echocardiography devices purchased as part of the "National Programme of Equal Accessibility to the Prevention and Treatment of Cardiovascular Diseases 2010-2012 POLKARD" [17], as well as the continuous education of medical staff and increasing knowledge of current guidelines [18]. Mean values of the left ventricular EF, in particular NYHA classes, were higher than in 2005 by $5 \%$ to $8 \%$, which may confirm that diastolic HF was diagnosed more often in the population of HF sufferers than previously. This is in line with world data and trends where, depending on the applied diagnosis criteria, the percentage of HFpEF ranges from $40 \%$ to $70 \%$ of $\mathrm{HF}$ patients $[2,19]$.

A significant change occurred in the use of quick diagnostic tests, measuring the concentration of NT-proBNP in 
blood plasma. In 2005 it was limited to only a few academic centres, whereas in 2013 these tests were available for more than $80 \%$ of the participating hospitals. The basic cause of the above observation was probably the recommendation of the ESC [20]. The mean values of NT-proBNP concentration in our analyses were significantly higher than threshold values and increased with NYHA class from 907 ng/L to 3312 ng/L, confirming the accuracy of the established diagnoses.

An important indicator of quality of HF treatment remains the accordance with ESC guidelines. The presented study was focused on the categories of medication ordered for patients on discharge from hospital, to be compared with data from other studies, and with the guidelines [21]. A representative group of 12,440 patients with HF, from 211 heart clinics in 21 European countries, including Poland, was analysed in the ESC Heart Failure Long-Term Registry [22] project (HFL-TR). About $40 \%$ of the HFL-TR population consisted of hospitalised patients, and this subpopulation can be considered as a comparative group for the results of our HF survey from 2013. In our survey, ACEI or ARB were recommended at discharge in $68.9 \%$ of patients and in $77.0 \%$ of subjects in the HFL-TR study, respectively: beta-blockers in $84.8 \%$ and $71.8 \%$; MRA in $57.9 \%$ and $55.3 \%$; diuretics in $85.9 \%$ and $83.6 \%$; and digoxin in $23.0 \%$ and $26.4 \%$, respectively. The presented data are also similar to data from the Atherosclerosis Risk Communities (ARIC) study assessing the quality of care for HF patients hospitalised due to acute or chronic HF [23]. In that analysis, patients with a principal diagnosis of HF had higher rates of prescription of ACEI or ARB in left ventricular dysfunction as compared to patients hospitalised for other causes: $64.1 \%$ vs. $56.3 \%$, and of beta-blocker: $81.4 \%$ vs. $77.9 \%$, respectively. The meaningful finding of the presented analysis is the poor prescription of ACEI or ARB in subjects treated for $\mathrm{HF}$ within internal wards because only half of them received these drugs at discharge. On the other hand, the number of subjects receiving MRAs increased in recent years and reached almost $60 \%$. One can speculate that the described phenomenon was the result of the recent recommendation to use spironolactone for the treatment of resistant hypertension and avoidance of the use of the combination of spironolactone and ACEI or ARB. Another reason might be the treatment of much older subjects in internal wards than in cardiology units [8].

During the period between HF surveys in 2005 and 2013, many changes in electrotherapy, such as the number of implanted devices, were observed. In our study, this was particularly visible in the higher percentage of HF patients with ICD - in $20057 \%$ of studied patients had an ICD, and in 2013 this figure was 23\%, which illustrates an improvement in the accessibility of this type of treatment for patients with HF.

\section{Strengths and weaknesses of the study}

A strength of the study is the large number of surveyed hospitalisations of HF patients. Diagnosis of HF was based on medical records reflecting the everyday clinical situation, which differs from model conditions of clinical studies, especially in the case of multi-morbidity, which can also be seen as a strength. The study also gave the chance to compare the results with the data from the previous study edition, i.e. the POLKARD 2003-2005: following certain parameters in time gives a dynamic view of the occurring changes and allows the formation of a better health policy, which in effect gives a greater chance for the optimisation of treatment quality.

The study also has several weaknesses. The study design is retrospective, which in some cases results in incomplete data and lack of definite standards of medical recording. Another limitation is the lack of dosing information for the drugs used in HF. The diagnostic and treatment criteria of HF were not verified.

\section{CONCLUSIONS}

In comparison to the analogous project run in 2005, an improvement in some areas of HF treatment was observed in Polish hospitals, such as echocardiography and natriuretic peptide measurement as well as beta-blockers and MRA prescription. At the same time, a meaningful decrease in ACEI or ARB usage in internal wards was observed, which might be the result of the ageing of the HF population and an increased number of comorbidities.

Funding: This work was supported by the National Science Centre in Poland (Grant No. UMO-2011/01/B/NZ7/02671) as a part of the project entitled: Project evaluation of diagnostics, treatment, and costs in patients with heart failure among randomly selected outpatient clinics and hospital wards - Part II.

\section{Conflicts of interest: none declared}

\section{References}

1. Ponikowski P, Voors AA, Anker SD, et al. Authors/Task Force Members. 2016 ESC Guidelines for the diagnosis and treatment of acute and chronic heart failure: The Task Force for the diagnosis and treatment of acute and chronic heart failure of the European Society of Cardiology (ESC)Developed with the special contribution of the Heart Failure Association (HFA) of the ESC. Eur Heart J. 2016; 37(27): 2129-2200, doi: 10.1093/eurheartj/ehw128, indexed in Pubmed: 27206819.

2. Guha K, McDonagh T. Heart failure epidemiology: European perspective. Curr Cardiol Rev. 2013; 9(2): 123-127, indexed in Pubmed: 23597298.

3. Working Group on Heart Failure of the Polish Cardiac Society. Heart failure in Poland - report on 2016. http://www.niewydolnosc-serca.pl/barometr.pdf.

4. Rywik TM, Koziarek J, Piotrowski W, et al. Trends in heart failure mortality in Poland between 1980 and 2010. Pol Arch Med Wewn. 2013; 123(12): 664-671, indexed in Pubmed: 24162363. 
5. Narodowy Fundusz Zdrowia. Statystyka JGP. https://prog.nfz. gov.pl/app-jgp/AnalizaPrzekrojowaSzczegoly.aspx?id=142 (22 Aug 2016).

6. Czech M, Opolski G, Zdrojewski T, et al. The costs of heart failure in Poland from the public payer's perspective. Polish programme assessing diagnostic procedures, treatment and costs in patients with heart failure in randomly selected outpatient clinics and hospitals at different levels of care: POLKARD. Kardiol Pol. 2013; 71(3): 224-232, doi: 10.5603/KP.2013.0032, indexed in Pubmed: 23575775.

7. Wizner B, Dubiel JS, Zdrojewski T, et al. Ogólnopolski program oceny diagnostyki, leczenia i kosztów u chorych z niewydolnością serca w losowo wybranych jednostkach lecznictwa otwartego i zamkniętego na poziomie podstawowym, wojewódzkim i specjalistycznym. Założenia i metodyka projektu realizowanego w ramach Narodowego Programu Profilaktyki i Leczenia Chorób Układu Krążenia: PolKARD 2003-2005. Folia Cardiologica. 2006; 13: 73-81.

8. Fedyk-Łukasik M, Zdrojewski T, Wizner B, et al. Heart failure management in Poland: The National Cardiovascular Disease Prevention and Treatment Program POLKARD, edition 2003-2005. Cardiol J. 2007; 14(6): 552-560, indexed in Pubmed: 18651521.

9. Wizner B, Dubiel JS, Opolski G, et al. Access to selected diagnostic procedures in the management of heart failure patients in Poland - POLKARD 2005. Kardiol Pol. 2010; 68(3): 265-272, indexed in Pubmed: 20411450.

10. McGlynn E, Asch S, Adams J, et al. The quality of health care delivered to adults in the United States. N Engl J Med. 2003; 348(26): 2635-2645, doi: 10.1056/nejmsa022615.

11. Ambrosy A, Fonarow G, Butler J, et al. The global health and economic burden of Hospitalizations for heart failure. J Am Coll Cardiol. 2014; 63(12): 1123-1133, doi: 10.1016/j.jacc.2013.11.053.

12. Fonarow GC, Abraham WT, Albert NM, et al. Factors identified as precipitating hospital admissions for heart failure and clinical outcomes: findings from OPTIMIZE-HF. Arch Intern Med. 2008; 168(8): 847-854, doi: 10.1001/archinte.168.8.847, indexed in Pubmed: 18443260.

13. van Deursen VM, Urso R, Laroche C, et al. Co-morbidities in patients with heart failure: an analysis of the European Heart Failure Pilot Survey. Eur J Heart Fail. 2014; 16(1): 103-111, doi: 10.1002/ejhf.30, indexed in Pubmed: 24453099.

14. Sosnowska-Pasiarska B, Bartkowiak R, Wożakowska-Kapłon B, et al. Population of Polish patients participating in the Heart Failure
Pilot Survey (ESC-HF Pilot). Kardiol Pol. 2013; 71(3): 234-240, doi: 10.5603/KP.2013.0034, indexed in Pubmed: 23575777.

15. Moreyra AE, Deng Y, Wilson AC, et al. MIDAS 18 study group. Incidence and trends of heart failure admissions after coronary artery bypass grafting surgery. Eur J Heart Fail. 2013; 15(1): 46-53, doi: 10.1093/eurjhf/hfs154, indexed in Pubmed: 23097068.

16. Samady H, Elefteriades JA, Abbott BG, et al. Failure to improve left ventricular function after coronary revascularization for ischemic cardiomyopathy is not associated with worse outcome. Circulation. 1999; 100(12): 1298-1304, indexed in Pubmed: 10491374

17. Ministerstwo Zdrowia: Narodowy Program Wyrównywania Dostępności do Profilaktyki i Leczenia Chorób Układu Sercowo-Naczyniowego na lata 2010-2012 POLKARD. www2. mz.gov.pl/.../program_polkard_08062010.pdf.

18. Parnicka A, Wizner B, Fedyk-Łukasik M, et al. Knowledge about heart failure in primary care: need for strengthening of continuing medical education. Cardiol J. 2013; 20(4): 356-363, doi: 10.5603/CJ.2013.0093, indexed in Pubmed: 23913453.

19. Butler J, Fonarow GC, Zile MR, et al. Developing therapies for heart failure with preserved ejection fraction: current state and future directions. JACC Heart Fail. 2014; 2(2): 97-112, doi: 10.1016/j.jchf.2013.10.006, indexed in Pubmed: 24720916.

20. Roberts E, Ludman AJ, Dworzynski K, et al. NICE Guideline Development Group for Acute Heart Failure. The diagnostic accuracy of the natriuretic peptides in heart failure: systematic review and diagnostic meta-analysis in the acute care setting. BMJ. 2015; 350: h910, doi: 10.1136/bmj.h910, indexed in Pubmed: 25740799.

21. Grupa Robocza 2012 ESC ds. Rozpoznania oraz Leczenia Ostrej i Przewlekłej Niewydolności Serca: Wytyczne ESC dotyczące rozpoznania oraz leczenia ostrej i przewlekłej niewydolności serca na rok 2012. Kardiol Pol. 2012; 70(supl. II): 101-176.

22. Anker SD, Maggioni AP, Dahlstrom U, et al. Heart Failure Association (HFA) of the European Society of Cardiology (ESC). Are hospitalized or ambulatory patients with heart failure treated in accordance with European Society of Cardiology guidelines? Evidence from 12,440 patients of the ESC Heart Failure Long-Term Registry. Eur J Heart Fail. 2013; 15(10): 1173-1184, doi: 10.1093/eurjhf/hft134, indexed in Pubmed: 23978433.

23. Blecker S, Agarwal SK, Chang PP, et al. Quality of care for heart failure patients hospitalized for any cause. J Am Coll Cardiol. 2014; 63(2): 123-130, doi: 10.1016/j.jacc.2013.08.1628, indexed in Pubmed: 24076281.

Cite this article as: Fedyk-Łukasik M, Wizner B, Opolski G, et al. Quality of care of hospitalised patients with heart failure in Poland in 2013: results of the second nationwide survey. Kardiol Pol. 2017; 75(6): 527-534, doi: 10.5603/KP.a2017.0040. 


\title{
Jakość opieki nad hospitalizowanymi pacjentami z niewydolnością serca w Polsce w 2013 roku wyniki drugiej edycji badania
}

\author{
Małgorzata Fedyk-Łukasik ${ }^{1}$, Barbara Wizner ${ }^{1}$, Grzegorz Opolski², Tomasz Zdrojewski ${ }^{3}$, Marcin Czech", \\ Jacek S. Dubiel ${ }^{5}$, Michał Marchel ${ }^{2}$, Tomasz Rywik ${ }^{6}$, Jerzy Korewicki ${ }^{6}$, Tomasz Grodzicki ${ }^{1}$ \\ 'Katedra Chorób Wewnętrznych i Gerontologii, Uniwersytet Jagielloński Collegium Medicum, Kraków \\ ${ }^{2}$ Katedra i Klinika Kardiologii, Warszawski Uniwersytet Medyczny, Warszawa \\ ${ }^{3}$ Zakład Prewencji i Dydaktyki, Katedra Nadciśnienia Tętniczego i Diabetologii, Gdański Uniwersytet Medyczny, Gdańsk \\ ${ }^{4}$ Szkoła Biznesu, Politechnika Warszawska, Warszawa \\ 5I Klinika Kardiologii, Uniwerytet Jagielloński Collegium Medicum, Kraków \\ ${ }^{6}$ Klinika Niewydolności Serca i Transplantologii, Instytut Kardiologii, Warszawa
}

\section{Streszczen i e}

Wstęp: Optymalne postępowanie diagnostyczno-terapeutyczne z pacjentami z niewydolnością serca (HF) jest kluczowym elementem w redukcji zarówno ponownych hospitalizacji, jak i umieralności w tej grupie chorych.

Cel: Celem pracy była ocena jakości opieki u hospitalizowanych pacjentów z HF w Polsce w 2013 r. i porównanie z wynikami podobnego badania przeprowadzonego w $2005 \mathrm{r}$.

Metody: Badania prowadzono od kwietnia do listopada 2013 r. w 260 oddziałach szpitalnych w Polsce: internistycznych i kardiologicznych. Podobnie jak w pierwszej edycji badania w 2005 r., specjalnie przeszkolona pielęgniarka kontaktowała się z jednym z lekarzy, który wypełniał ankiety charakteryzujące stan kliniczny i przebieg hospitalizacji 5 pacjentów z HF wypisanych ostatnio z oddziału w stanie poprawy. Niewydolność serca nie musiała być główną przyczyną hospitalizacji.

Wyniki: Średni wiek 1300 hospitalizowanych pacjentów wynosił 72,1 roku i wzrósł o 2,3 roku od 2005 r. Odsetek pacjentów zaklasyfikowanych do IV klasy wg New York Heart Association zmniejszył się z 28,5\% w 2005 r. do 22,1\% w 2013 r.. W 2013 r., w porównaniu z badaniem w 2005 r., więcej pacjentów miało zdiagnozowane choroby współistniejące tj. nadciśnienie (odpowiednio: $79,5 \%$ vs. $71,0 \%)$, cukrzycę (46,2\% vs. 33,2\%), przewlekłą niewydolność nerek (33,4\% vs. 19,4\%). Dostępność echokardiografii w ciągu ostatnich lat poprawiła się, badanie było możliwe do wykonania w obrębie 98,9\% ankietowanych oddziałów szpitalnych (93\% w 2005 r.). Jednak, na podstawie informacji uzyskanych od lekarzy, w trakcie ostatniej hospitalizacji badanie wykonano u 60,2\% ankietowanych pacjentów (58,8\% w 2005 r.). W 2013 r. oznaczenie N-końcowego propeptydu natriuretycznego typu B było dostępne dla 80,8\% badanych oddziałów szpitalnych (12,8\% w 2005 r.); podczas ostatniej hospitalizacji badanie wykonano u 31,3\% hospitalizowanych pacjentów z HF (3,3\% w 2005 r.). Inhibitory konwertazy angiotensyny (ACEI) lub antagonistów receptora angiotensyny (ARB) zalecono 68,9\% wypisywanym z oddziału pacjentom z HF, beta-adrenolityk - 84,8\%, antagonistę aldosteronu - 57,9\%, diuretyk - 85,9\%, a digoksynę - 23\% wypisywanych osób. W 2005 r. odsetek chorych przyjmujących kolejno wymienione grupy leków kształtował się następująco: 85,9\%; 76,0\%; 65,4\%; 88,9\% i 38,4\%. Zmniejszona częstość stosowania ACEI lub ARB wynika z ich rzadszego przepisywania na oddziałach internistycznych — w 2005 r. były stosowane u 84,3\% pacjentów, a w 2013 r. zalecono je 55,6\% chorym.

Wnioski: W porównaniu z analogicznym projektem zrealizowanym w 2005 r. w pewnych obszarach opieki nad pacjentem z HF w lecznictwie zamkniętym odnotowano poprawę, szczególnie w zakresie stosowania echokardiografii, oceny stężenia peptydów natriuretycznych oraz przepisywania beta-adrenolityków i antagonistów aldosteronu. Zwraca uwagę wyraźne zmniejszenie przepisywania ACEI lub ARB, co może być wynikiem starzenia się populacji pacjentów z HF oraz wzrostu liczby chorób współistniejących.

Słowa kluczowe: niewydolność serca, postępowanie w niewydolności serca, pacjenci hospitalizowani, jakość opieki

Kardiol Pol 2017; 75, 6: 527-534

\section{Adres do korespondencji:}

prof. dr hab. n. med. Tomasz Grodzicki, Katedra Chorób Wewnętrznych i Gerontologii, Uniwersytet Jagielloński Collegium Medicum, ul. Śniadeckich 10, 31-531 Kraków, tel: +48 1242488 00, faks: +48 1242488 54, e-mail: tomekg@su.krakow.pl

Praca wpłynęła: 10.10.2016 r. Zaakceptowana do druku: 23.01.2017 r. Data publikacji AoP: 07.03 .2017 r. 